\title{
THE ROLE OF INTEGRATED TERRITORIAL INVESTMENTS IN SUPPORTING THE COMPETITIVENESS OF ENTERPRISES BY THE EXAMPLE OF BIALYSTOK FUNCTIONAL AREA
}

\author{
ANNA BUSŁOWSKA, ${ }^{1}$ KAMIL WALIGÓRA ${ }^{2}$ \\ University of Bialystok, Faculty of Economics and Management, POLAND \\ 1 e-mail: a.buslowska@uwb.edu.pl \\ 2 e-mail: k.waligora@uwb.edu.pl
}

\section{RECEIVED \\ ACCEPTED \\ JEL \\ CLASSIFICATION}

KEYWORDS

ABSTRACT
18 January 2018

2 September 2018

$\mathrm{H} 77, \mathrm{O} 11, \mathrm{O} 21, \mathrm{O} 22, \mathrm{O} 38$

integrated territorial investment, urban functional area, entrepreneurship, economic growth

Integrated Territorial Investments (ITI) is a new support instrument dedicated to solving specific territorial problems of urban functional areas. About $6 \%$ of the allocation of the Regional Operational Program for Podlaskie Voivodship 2014-2020 is planned for realization of activities implemented in frame of ITI in the Białystok Functional Area (BFA). This support is for: strengthening the potential and competitiveness of the region's economy, enhancing competences and qualifications, low carbon economy and improving social cohesion. In particular, the support for business development by increasing investment attractiveness is planned. Allocation of ITI for this purpose is ca. 13,7 mln EUR. The aim of the article is to assess the state of entrepreneurship development and the range of support for the competitiveness of enterprises in the BFA in frame of ITI instrument. It will be presented a case study of projects implementing in BFA in frame of ITI instrument to support enterprise development and research conducted by Bialystok Functional Area Association (BFAA). Case study will be preceded by an analysis of the competitiveness of the local entrepreneurship and analysis of theoretical issues.

\section{Introduction}

Functional Urban Areas (FUAs) provide a comprehensive look at the problems and challenges of modern cities. The term derives directly from the concept of the daily urban system of Berry from 1973. It concerned the designation of the area around the city, the scope of which is determined by everyday connections related to constant commuting to work, places of study, etc. (Bartosiewicz, 2016). FUA's theory assumes, that the development 
of settlement units is not independent, but that the flow of persons, goods, services, capital and information between the central city (core) and the adjacent units is closely linked. According to Koncepcja Przetrzennego Zagospodarowania Kraju 2030 (KPZK) (2011), FUA is a settlement system composed of administratively separate units maintaining spatial continuity. It consists of a city and an urbanized area that is functionally linked to the city. In the economic theory, functional area is included in the Core Area Theory i.e. the area created around a significant urban centre, having mutual connections and burdens regarding the exchange of people, goods, services, capital and information (Szafranek, 2015) It falls into the concept of a core and a periphery by J. Fridman, who indicated that manufacturing and service activities are located in the most developed regions, mainly in big metropolitan centers. Additionally, these are the centers that dominate over peripheries, which development is subordinated as they provide services to central areas. The centers aim to dominate in various areas of social, economic and cultural activities. Therefore, it is important to stimulate the development of such central areas in the regions (Grosse, 2002). Szafranek (2017) notes, that in the functional area between the center and its surroundings must be a mutual connection. Both the center and its sphere of influence perform important, complementary functions, which depend on the level of socio-economic development and functional, spatial diversity of FUAs.

KPZK (2011) identifies four basic types of FUAs: voivodeship, regional, sub-regional and local. The basis for the diagnosis for the MOF typology found in KPZK 2030 was delimitation functional urban areas in the ESPON 1.4.3 project "Study on urban function". Delimitations arising from documents on regional levels are not always consistent with the results carried out by the EU. In 2012, the Ministry of Regional Development elaborated criteria for deleting FUAs according to the methodology using three groups of indicators, developed by Śleszyński. The most important role in urban and regional policy is played by functional areas of voivodship and regional cities. (Kociuba, 2015)

Integrated territorial investment (ITI) is a new European Union (EU) financial instrument for 2014-2020, that supports the approach of FUAs. The essence of this instrument is to provide the mechanism of integrated answers to various needs formed within the functional areas development strategy. It is a results of assumptions of EU regional policy indicating that cities and their networks should become a link of socio-economic development of countries and regions. (Szafranek, 2017) Partnership Agreement (Umowa Partnerstwa, 2015) introduced an obligatory character of the ITI instrument in voivodeship cities and additionally it was made possible to implement ITI in regional/subregional cities and towns and in the areas functionally connected to them. The basic conditions that were linked with the mobilization of ITI funds includes among others: preparation of ITI strategy, signing the agreement to implement ITI in a voivodeship with the managing institution of Regional Operational Programme (ROP), possessing proper institutional ability, establishing institutionalized partnership form. (Zasady realizacji.., 2013). In this way, conducting policy towards FUAs constitutes a significant support factor that better defines their development potentials and is a comprehensive solution to the already existing problems (Krajowa Polityka Miejska 2023, 2015).

On the basis of the above, the following definition of ITI can be adopted - as a socio-economic development tool of the cities' functional areas, implemented as a result of institutionalized form of cooperation between selfgovernments for the support of integrated and comprehensive activities resulting from territorial strategies and implemented with the participation of EU funds.

In the financial perspective 2014-2020, ITI instrument in Poland is implemented by $17^{1}$ functional areas of voivodeship cities and 7 regions/sub-regions: Jelenia Góra Agglomeration, Wałbrzych Agglomeration,

${ }^{1}$ In Lubuskie Voivodship there are 2 functional areas with the core in Gorzów Wielkopolski and Zielona Góra. 
Silesian Voivodeship's southern sub-region, Silesian Voivodeship's northern sub-region, Silesian Voivodeship's western sub-region, Kalisz and Ostrów Wielkopolski as well as Koszalin-Kołobrzeg-Białogard Functional Area. (Zintegrowane..., 2017) ITI aims to ensure the long-term co-operation of municipalities of functional areas through cooperation in projects aimed at solving common socio-economic, environmental and demographic problems. One such problem is also promotion and development of entrepreneurship. Of the twenty four functional areas in Poland implementing ITI, support for strengthening the competitiveness of enterprises is realized in sixteen FUAs.

\section{Method}

The paper was developed on the basis of case study analysis and research conducted by Bialystok Functional Area Association (BFAA): "Strategic monitoring of urban functional areas implementing Integrated Territorial Investments in Poland (Pilot Study), Report 1. Strategic indicators at voivodship level” (Mierzyńska, Perło, Truskolaski, 2016). The research period covered the years 2010-2014 and concerns the topic of increasing the competitiveness of enterprises by co-financing from Integrated Territorial Investment. The paper contains also a comparison of the projects (case studies), that are implementing in frame of Integrated Territorial Investment Strategy of Białystok Functional Area for the years 2014-2020 (2016) in that field. These analysis were preceded by introduction to the theory of functional areas and integrated territorial investments. The aim of the research was to assess entrepreneurship development and the range of support of the competitiveness of enterprises in the Bialystok Functional Area (BFA) from ITI tool. The main research questions concerned following issues: what is situation of entrepreneurship development in the Podlaskie voivodship; what kind of undertakings are planned to be co-financed from ITI tool in the area of strengthening competitiveness and entrepreneurship in the BFA and what effects it will bring?

\section{Results}

\section{Entreppeneurship in Bialystok Functional Aprea - main data}

The total sum of 6.2 mld euro is devoted for the implementation of the ITI strategies in Poland. In BFA, it is the sum of $76 \mathrm{mln}$ euro and for the support of entrepreneurship it is $12.15 \mathrm{mln}$ euro (16\% of the joint ITI allocation). BFA is situated in the area of $1728 \mathrm{~km}^{2}$ ( $8.6 \%$ of Podlasie's area) and $34.7 \%$ of Podlaskie Voivodeship citizens live here (about 413 thousand inhabitants). It includes 10 municipalities. BFA belongs to medium-sized functional areas (14 $4^{\text {th }}$ position in $24^{\text {th }}$ FUAs in Poland), but compared to the voivodeship cities implementing ITI, it is rather small (11 th position). (Mierzyńska, Perło, Truskolaski, 2016)

Below, there are a few of the selected indices presenting the condition of entrepreneurship in the BFA area as well as in Podlaskie Voivodeship that are the subject to the analysis within the research conducted by BFAA. These indices were identified as strategic for the implementation of EU objectives regarding the improvement in companies' competitiveness² (Mierzyńska, Perło, Truskolaski, 2016)

The general index of BFA entrepreneurship i.e. the relation of the number of economic entities in general per 10 thousand inhabitants, places itself at the level of 1073 and is one of the lowest $-19^{\text {th }}$ position in 24 FUAs.

\footnotetext{
2 Report contains wider analysis of the indices (jointly 14 for each of the voivodeship. Some of the data are only collected at the level of voivodeship and therefore in Report there are only general conclusions drawn from these indices' analysis. FUAs as poles of development of voivodeship, have the greatest impact on development and such an analysis is justified.
} 
It indicates quite low entrepreneurship of this region. Also, the investment outlays in companies in relation to GDP in Podlaskie Voivodeship are not the highest. In 2014, it amounted to $7.3 \%$, which placed this region in $14^{\text {th }}$ position in vivodeship FUA's ranking and constituted $83 \%$ of the national average. The positive aspect is that in spite of high dynamics in 2010-2014, this index in that period increased by $26 \%$. The target value assumed in the ROP of Podlaskie Voivodeship for 2014-2020 in 2023 is supposed to reach $11.1 \%$. The index describing the gross fixed capital formations in national economy reflects the need to support entrepreneurship and competitiveness. In 2013, the formations amounted to $7766 \mathrm{mln}$ PLN and constituted only 40\% of the national average, which was $19481 \mathrm{mln}$ PLN. The growth rate of this index in the research period was also low - on average year by year it grew by about $2 \%$. Next index, the gross turnover profitability rate is greatly below the average $-79 \%$ of the average in 2014 and amounted to $3.4 \%$. It is one of the worst results in the country. The support within ROP assumes the increase in this index to $3.91 \%$ in 2023 . The last strategic index is the average participation of innovative companies in the general number of industrial companies and from the service sector. In 2014, it amounted to about $14.7 \%$ and was slightly above the average $-102 \%$, which placed the region in 6th position. The assumed value of this index in 2023 is supposed to reach $23.4 \%$ for industrial companies and 12 for the service ones.

\section{Supporting businesses within integrated territorial investments in Bialystok Functional Area - examples}

The activities determined in ITI BFA Strategy (2016), when it comes to supporting companies, concentrate on the priority to support investors and by doing so boosting entrepreneurship. There are two basic activities foreseen to

Table 1. Projects supporting the investment attractiveness in BFA

\begin{tabular}{|c|c|}
\hline Applicant & Project characteristics \\
\hline 1 & 2 \\
\hline City of Białystok & $\begin{array}{l}\text { The project's objective is to improve the conditions for running and developing economic activity by comprehensive } \\
\text { preparation of areas located in Krywlany, which constitute a part of the Białystok Sub-Zone of the Suwałki Special } \\
\text { Economic Zone. Service activities, business premises covering the area of above } 2000 \mathrm{~m} 2 \text { as well as industrial facilities } \\
\text { are supposed to be developed here. } \\
\text { Current project's status: approved application's assessment }\end{array}$ \\
\hline Łapy Municipality & $\begin{array}{l}\text { The municipality is implementing an integrated project, which in one part pertains to providing utility infrastructure } \\
\text { to the areas and in the second part - the improvement in transport accessibility. Providing investment area's utility } \\
\text { infrastructure is about preparing for investment the post-industrial area i.e. water and sewage holding tank of the former } \\
\text { 'Sugar Factory in Łapy' ('brown-field' type). The second project relates to building the local road - Nilskiego-Łapińskiego } \\
\text { as well as two sections of Cukrownicza street that will improve communication accessibility to investment areas. } \\
\text { Current project's status: co-financing agreement }\end{array}$ \\
\hline Supraśl Municipality & $\begin{array}{l}\text { The municipality is implementing an integrated project, which in one part pertains to providing utility infrastructure } \\
\text { to the areas and in the second part - the improvement in transport accessibility. Rebuilding and building streets (Kodeksu } \\
\text { Supraskiego street with extension to Rymark street as well as the roads around investment areas) aim at improving } \\
\text { transport links with voivodeship road No. } 676 \text { and it will have a positive impact on communication's quality in Supraśl, } \\
\text { which is a health resort. Providing utility infrastructure to the areas will influence the development of the municipality } \\
\text { on the basis of entrepreneurship of such fields as tourism, recreation, health care by providing high standard of leisure } \\
\text { and tourism products' functioning. } \\
\text { Current project's status: co-financing agreement }\end{array}$ \\
\hline Zabłudów Municipality & $\begin{array}{l}\text { The municipality is implementing an integrated project, which in one part pertains to providing utility infrastructure to the } \\
\text { areas and in the second part - the improvement in transport accessibility. The subject of the first project is to provide utility } \\
\text { infrastructure (e.g.: water and sewage) to unutilized areas ('green-field' type) belonging to the Municipality in order to boost } \\
\text { entrepreneurship. The second project relates to the implementation of activities connected with rebuilding the national road } \\
\text { No.19 in order to facilitate access to the Municipality's investment areas. } \\
\text { Current project's status: approved application's assessment }\end{array}$ \\
\hline
\end{tabular}

Source: Municipalities' data (September, 2017). 
increase investment attractiveness of BFA. The first one relates to supporting investors and innovative undertakings and building durable innovative potential of BFA by developing cooperation in the field of R\&D. In activity 2, financed within the ITI instrument, apart from providing utility infrastructure to investment areas destined for companies, there is also the improvement in accessibility to these areas. These are the so-called 'hard' projects connected with providing the necessary infrastructure including, among other things, building and rebuilding: roads, sanitary sewage, water supply network, cord telephone lines, lighting, technological channels. Table 1 presents the characteristics of the undertakings supporting the investment attractiveness planned by 4 municipalities of the BFA.

All the above mentioned applicants have already submitted applications for co-financing of the planned projects within the ITI instrument. The agreements were signed in both cases. The remaining 2 projects are at the stage of assessment and approval of the co-financing applications.

The direct result of the undertakings implemented within the ITI instrument in the field of entrepreneurship (activity 1.2 of the BFA ITI Strategy) will be about 62 ha of land of the prepared investment areas, 15 investments of entrepreneurs located in those areas as well as $3 \mathrm{~km}$ of built/rebuilt roads facilitating the accessibility of the given investment areas.

Table 2. Results of projects supporting investment attractiveness of BFA municipalities

\begin{tabular}{|c|c|c|c|c|c|}
\hline $\begin{array}{c}\text { Municipality } \\
\text { Indices name }\end{array}$ & Białystok & Łapy & Supraśl & Zabłudów & Total \\
\hline The number of investments located in the prepared investment areas (items) & 6 & 4 & 3 & 2 & 15 \\
\hline Acreage of the prepared investment areas (ha) & 44 & 10.78 & 2.48 & 4.6 & 61.86 \\
\hline Total length of new roads $(\mathrm{km})$ & 0 & 0.7 & 1.37 & 0 & 2.07 \\
\hline Total length of the rebuilt or modernized roads $(\mathrm{km})$ & 0 & 0.26 & 0 & 0.38 & 0.64 \\
\hline
\end{tabular}

Source: Municipalities' data (September, 2017).

The anticipated results of the investment refer also to such aspects as:
a) utilizing the undeveloped assets belonging to a municipality by extending the offer to new investment areas;
b) providing the conditions for the creation of new workplaces and so reducing negative phenomena connected with unemployment (among others, migrations);
c) increased interest in the municipality of potential investors;
d) enhancing accessibility to investment areas.
It should be noticed that the implementation of the above mentioned investments will not solve all the BFA's problems in the field of supporting companies and entrepreneurship. The assumed activities can be treated as a good first step for building investment attractiveness and drawing entrepreneurs to these areas. Further activities should develop and complement the implemented projects, e.g. in the field of economic promotion and facilitations for entrepreneurs in running economic activity in the given area.

\section{Conclusions}

According to the issues presented in the text and by relating to wider conclusions of the research conducted by BFAA, the following conclusions and recommendations can be drawn: 
1. Not all the BFA's municipalities are engaged in the activities connected with supporting competitiveness of companies in frame of ITI allocation. However, the activities in this field within functional areas constitute the result of not only ITI relations, but also particular municipalities, which implement the activities connected with creating the conditions for the companies' competitiveness.

2. The Podlaskie Voivodeship is in the class of regions that they diagnosed the greatest need for support in the area of increasing competitiveness, by allocating for this purpose a relatively high level of the ITI allocation.

3. The integrated approach to the development of functional areas is a positive direction of changes aimed at building a culture of partnership and competitiveness in the FUAs.

On the basis of the study you can also draw a general conclusion. The strategic indicators proposed in the ITI strategies and ROPs prevent efficient monitoring of the development of FUAs. They were often defined imprecisely on the basis of experts' calculations and not on public statistics, which makes systematic analysis impossible.

\section{References}

Bartosiewicz, B. (2016). Obszary funkcjonalne małych i średnich miast w Polsce - koncepcja badawcza. Studia Ekonomiczne. Zeszyty Naukowe Uniwersytetu Ekonomicznego w Katowicach, 279, 234-244.

Grosse, T.G. (2002). Przegląd koncepcji teoretycznych rozwoju regionalnego. Studia Regionalne i Lokalne, 1 (8), $25-48$.

Kociuba, D. (2015). Miejskie obszary funkcjonalne - wyzwania planistyczne. Studia Miejskie, 18, 39-83.

Koncepcja przestrzennego zagospodarowania kraju 2030 (2011). Monitor Polski poz. 252. Retrieved from: http://mr.bip.gov.pl/strategierozwoj-regionalny/17847_strategie.html (August 30, 2017).

Krajowa Polityka Miejska 2023 (2015). Ministerstwo Rozwoju. Retrieved from: https://www.mr.gov.pl/media/10252/Krajowa_Polityka_ Miejska_20-10-2015.pdf.

Mierzyńska, D., Perło, D., Truskolaski, T. (2016). Monitorowanie strategiczne miejskich obszarów funkcjonalnych realizujących Zintegrowane Inwestycje Terytorialne w Polsce, Raport 1. Wskaźniki strategiczne na poziomie województw. Stowarzyszenie Białostockiego Obszaru Funkcjonalnego. Retrieved from: http://bof.org.pl/pl/dokumenty.

Umowa Partnerstwa. Programowanie perspektywy finansowej 2014-2020 (2015). Ministerstwo Rozwoju. Retrieved from: https://www. funduszeeuropejskie.gov.pl/media/14132/_Umowa__Partnerstwa_zmieniona_012016.pdf.

Strategia Zintegrowanych Inwestycji Terytorialnych Białostockiego Obszaru Funkcjonalnego na lata 2014-2020 (2016). Białostocki Obszar Funkcjonalny.

Szafranek, E. (2015). Zintegrowane Inwestycje Terytorialne jako narzędzie budowy potencjału obszarów funkcjonalnych. Przykład Kędzierzyńsko-Kozielskiego subregionalnego obszaru funkcjonalnego. In: E. Sobczak, D. Głuszczuk, M. Obrębalski,Gospodarka (eds.), Gospodarka regionalna w teorii i praktyce (pp. 109-118). Wrocław: Uniwersytet Ekonomiczny.

Szafranek, E. (2017). Miejskie obszary funkcjonalne a kształtowanie spójności terytorialnej. Prace naukowe Uniwersytetu Ekonomicznego we Wrocławiu, 467, 113-128.

Zasady realizacji Zintegrowanych Inwestycji Terytorialnych w Polsce (2013). Ministerstwo Rozwoju Regionalnego. Retrieved from: https://rpo.slaskie.pl/dokument/zasady_realizacji_it_w_polsce.

Zintegrowane Inwestycje Terytorialne (2018). Retrieved from: https://www.funduszeeuropejskie.gov.pl/strony/o-funduszach/zasadydzialania-funduszy/zintegrowane-inwestycje-terytorialne (August 30, 2017).

Cite this article aS: Busłowska, A., Waligóra, K. (2018). The role of Integrated Territorial Investments in supporting the competitiveness of enterprises by the example of Bialystok Functional Area. European Journal of Service Management, 3 (27/2), 73-78. DOI: 10.18276/ ejsm.2018.27/2-09. 